Extract from JOURNAL, SOUTHEAST ASIAN HISTORY March, 1967

\title{
The Philippine Political Party System
}

\author{
By.
}

Carl H. Lande

East Asian Series, Reprint No. 5

INTERNATIONAL STUDIES CENTER FOR EAST ASIAN STUDIES

THE UNIVERSITY OF KANSAS

Lawrence, Kansas 
CENTER FOR EAST ASIAN STUDIES

1. The Patrimonial Thesis and Pre-Modern Japanese Herrschaft, by Norman Jacobs.

2. The Phantom Slasher of Taipei: Mass Hysteria in a Non-Western Society, by Norman Jacobs.

3. Early Chinese Economic Influences in the Philippines, by Edgar Wickberg.

4. Some Aspects of Korean Acculturation and Value Orientation Since 1950, by Felix Moos.

5. The Philippine Political Party System, by Carl H. Lande.

6. Religion and Politics in Japan: The Case of the Soka Gakkai, by Felix Moos.

7. Some Aspects of Park Chang No Kyo-A Korean Revitalization Movement, by Felix Moos.

8. The Philippines, by Carl H. Lande. 


\title{
THE PHILIPPINE POLITICAL PARTY SYSTEM
}

\author{
Carl H. Lande
}

The University of Kansas

\section{THE MAIN CHARACTERISTICS OF THE SYSTEM}

The main characteristics of the Philippine political party system since the achievement of Philippine independence in 1946 have been the following:

1. It is a two party system. Two major parties, the Nacionalistas and the Liberals, dominate the scene. Their nation-wide combined vote at the six post-war presidential elections held since 1946 averaged 94 per cent of the votes cast. At both the eleven senatorial elections and the six elections for members of the House of Representatives held during the same period, the combined two-party vote was also 94 per cent. At the five gubernatorial elections held since 1947, the corresponding figure was 97 per cent.* In none of these election years did the combined two-party vote for any of these offices fall below 70 per cent. ${ }^{1}$ While minor parties have appeared from time to time, few have remained active for an extended period of years, and none has seriously threatened to replace either of the two existing major parties as the governing party or as the principal party of the opposition.

2. Margins between the strengths of the major parties are substantial but not extreme. At the average post-war presidental election, the difference between the nation-wide vote for the candidates of the two major parties was 17 per cent. The corresponding figure in senatorial, congressional and gubernatorial elections was 12,20 and 27 per cent respectively. In no single year, at any of these elections, did the strength of one party exceed that of the other by more than 40 per cent of the votes cast. ${ }^{2}$

3. The major parties trade power at frequent intervals. After the first post-war presidential election of 1946, at which the

- The percentages for each party include both the official party candidates and "rebel" candidates claiming affiliation with the party concerned.

1. In 1957 Manuel Manahan of the Progressive Party of the Philippines and Claro Recto of the Nationalist-Citizens Party won 21 and 8 per cent of the votes respectively. 
Presidency was won by the secessionist Liberal Wing of the old Partido Nacionalista, subsequently re-named the Liberal Party, control of the Presidency has shifted back and forth between the parties on three occasions, in 1953, 1961, and 1965. Thus neither party, since the war, has held the Presidency for more than two consecutive four year terms. The cycles of alternating party control in the House of Representatives and the Senate have followed a similar pattern, though there the picture has been somewhat confused by a high incidence of post-election party switching by members of Congress.

4. The parties have controlled the government for approximately equal lengths of time. Between the first post-war elections and the end of 1966, the Nacionalista and Liberal parties have held the Presidency for 9 and 11 years respectively.

What has been described so far is hardly unusual. Competitive two-party systems are common in constitutional democracies Other features of the Philippine party system to be described below, are less common, however and therefore are of special interest.

5. The two major parties are identical. If each party is viewed as a whole and over time, one finds the two to be alike in all significant respects.

Neither party, over the long run, has been especially associated with any region. Each has maintained strong local and provincial organizations and a substantial electoral following in all regions of the country, and each has taken pains to champion the interests of every region as vigorously as has its opponent. True, each presidential and vice presidential candidate has won a substantially larger share of the votes in his home province and region than elsewhere, and each successful presidential candidate, when in office, has shown a special solicitude for the welfare of his region and province-mates. But an examination of the nation-wide distribution of votes at congressional and gubernatorial elections shows neither party to be exceptionally strong, consistently, in any region of the country. Indeed, provincial deviations from the nation-wide pattern of party voting have been fairly small, and have grown smaller over the years. Thus in 1961, the percent deviation of the average congressional district from the nation-wide average vote for Nacionalista congressional candidates was 14 per cent.

The two parties also are alike in the intensity of their concern for the welfare of various organized and unorganized interests.

2. At the gubernatorial, elections of 1955 , Nacionalista and Liberal Party candidates won 67 and 27 per cent of the votes respectively. 


\section{THE PHILIPPINES}

As a cause or consequence of this fact, neither party, over the long run, has obtained more consistent support from the members of any interest group than has its rival. Instead, all interest groups have taken pains to avoid becoming closely identified with either party. All have taken pains to ingratiate themselves with whichever party happened to be in power, while maintaining ties, through some of their members, with the party temporarily in opposition.

Finally, both parties are alike in seeking - and obtaining electoral support from amongst all social strata, and both have avoided adopting class-oriented ideological positions in order to be able to win such support.

6. Party-switching is common. A shift in popular support from one party to the other, or the expectation of such a shift, generally leads to changes of party allegiances by many professional politicians eager to remain on the side of those in power. Thus after the elections of 1961, when the Presidency passed from Nacionalista to Liberal hands, twenty-one newly-elected Nacionalista members of the House of Representatives bolted their party's leadership and joined with Liberal members of the House in voting for the Liberal candidate for the Speakership. Most of these Nacionalistas ultimately joined the Liberal Party. Even more striking, two of the Nation's post-war presidents have been men who quit one party shortly before the elections at which they won the Presidency under the banner of the opposing party. Finally, party-switching is common among the electorate at large. This is reflected in the fact that the average increase or decrease in Nacionalista Presidential polling strength between successive elections since 1946 has been 16 per cent. The corresponding figures for elections for the Senate, The House of Representatives and governorships have been 6 and 18 and 14 per cent respectively.

7. Intra-party solidarity is weak. This fact is demonstrated by the large number of "rebel candidates," who run for public office. These are party members who, having failed in their efforts to have themselves named their parties' "official candidates", run for office nonetheless despite the fact that by doing so, they will assure the defeat of their party's official candidates at what otherwise might have been certain victories. In the congressional elections of 1965 for example, one or both partics were plagued by rebel candidacies, or declared a "free zone" (an arrangement under which no party member is made the "official candidate", but all who choose to run are given the party's 


\section{THE PHILIPPINES}

blessing) in 37 out of the country's 104 congressional districts. ${ }^{3}$ In the election campaign the weakness of party solidarity also is reflected by the existence of many arrangements for mutual help between candidates of opposite parties running for different offices. After the elections are over, the lack of party solidarity may be observed in the Congress, where party unity in voting on legislation is the exception rather than the rule.

\section{IDENTICAL PARTIES: CAUSES}

For students of comparative politics, the most unusual and therefore most interesting characteristic of the Philippine party system is the identicalness of the two major parties. The remainder of the present paper will be devoted mainly to an attempt to find the reasons for this peculiarity, to an exploration of its consequences, and to a consideration of changes which may occur in this and other features of the Philippine party system in the foreseeable future.

Why are the major parties identical? One explanation, often advanced by both native and foreign observers of Philippine politics but not convincing to the writer, is that the two parties are alike because both are parties of the rich. The argument rests on two essentially Marxian assumptions: that political parties are the agents of specific social classes, and that two parties representing the same social class cannot be expected to differ from one another to any significant degree.

Yet even if it were true that both major parties in the Philippines are upper class parties, the second assumption need not follow. There might remain many important issues which could divide the upper class - the priority to be given to the needs of industry or agriculture, the political role of the Church, the desirability of cultural identification and political ties with Asia on the one hand and with the West on the other - which still might produce two easily distinguishable upper-class parties. In fact, however, the first assumption has little more applicability to the Philippines than the second. Philippine parties are not to be dismissed simply as parties of the upper class. True, the high cost of election contests and the requirement that each candidate meet most of the cost of his own campaign assure that virtually all holders of high offices will be men of substantial means. But it is not enough to look at the socioeconomic attributes of a party's leaders in order to know whose interests it represents. Both parties depend for their success at the polls upon the electoral support of the common people. And in a

3. These 37 districts do not include those where there were but very weak rebel party candidates or former members of major parties who called themselves independent candidates. 
setting characterized by close ind intensive two-party competition for the votes of a mass electorate possessed of extensive experience in the self-interested employment of their votes, neither party could survive if it did not devote considerable attention and substantial resources to the satisfaction of the needs of the common people.

In thus rejecting the Marxian explanation of the identicalness of the two parties, it is suggested that a recognition of the multi-class character of both parties is essential to an understanding of the Philippine party system. The next task is to discover how it is possible for each party to satisfy the needs of all regions, interests and social strata simultaneously, and to do this to a degree sufficient to prevent the permanent defection of any regional interest or stratum to the opposing party.

In most party systems with which students of politics are familiar, party identification is to be explained at least by a prior categorical bond among the party's adherents. That is to say, the bulk of those who support a certain party are drawn to it because of their common membership in some extra-political category or group for whose welfare that party has demonstrated a special solicitude. The categorical ties which draw individuals toward particular parties may be ones of social class. Alternatively, they may be ones of common national origin, tribe, religion, occupation or ideological persuasion.

This is not the case in the Philippines. There, those associated with each party are bound together in large part by networks of interpersonal alliances both between individuals of equal status and those of unequal status. These alliances cut across many of the categorical boundaries that in most modern democracies separate the adherents of one party from those of another.

We shall examine these networks of personal ties, at greater length below. Before we do so, however, it may be useful to inquire why Filipinos rely so heavily upon structure of this type when they organize themselves not only for politics but for a wide variety of other purposes as well. Briefly, they do so because of three characteristics of Filipino behaviour: a preoccupation with the particular; a strong attraction to the alternative roles of power-wielding patronship and dependent clientship; and a strong tendency toward parochialism. By this we mean the following:

Particularism. Filipinos in general display a high degree of interest in what is specific, concrete and near at hand in space and time, and a relatively low degree of interest in what is general, abstract and remote. This bias in favor of the particular may be observed in the sphere of political perception. Specific office holders and their tangible accomplishments loom large. Awareness of and interest in government agencies and programs is relatively 


\section{THE PHILIPPINES}

dim. The same particularism is displayed in political loyalties: Among political activists, attachment to specific leaders is far stronger and more enduring than attachment to political parties and other political groups. Among public servants, loyalty to specific superiors or patrons is much stronger than institutional loyalty to agencies as such. These patterns of perception, interest and affiliation, in turn, are accompanied by a corresponding pattern of skill: Filipinos display great adeptness in satisfying their concrete private needs and those of their relatives and friends through the manipulation of individual power-holders. They display far less skill in the creation and employment of organizations capable of achieving the broader, categorical goals of groups through collective action.

There is a social-structural explanation for this emphasis upon the particular at the expense of the categorical: Philippine society is structured to a relatively slight degree by discrete multi-member groups, but to a relatively high degree by what anthropologists have termed "dyadic" relationships. A "dyad" is a pair of individuals tied together for purposes of cooperation. Dyadic cooperation typically involves the provision of mutual help in the pursuit of the particular private goals of each of the two members of the dyad. Because of its small size, however, a dyad is ill-suited for a type of cooperation common in large multi-member groups:- the collective pursuit of shared goals of a categorical nature, distinct from the particular aims of each member.

The differences in structure and function between large multimember groups and dyads account for differences in their modes of composition: The former tend to be composed of individuals who are alike, the latter, of pairs of individuals who differ from each other. The reasons for this are the following: Collective action of the type well suited to a large group assumes that the group's members have some attribute in common. It is their awareness of this common attribute that leads them to put aside their private objectives while pursuing a "higher" collective goal thought to be in the enlightened interest of them all. Dyadic cooperation, on the other hand, is based not on the principle of shared goals but on the principle of exchange. It is most useful for persons who differ from one another in what they need and what they have to offer. And it is confined to particular objects. Thus a farmer and a fisherman engaged in dyadic cooperation exchange the rice needed by one for the fish needed by the other. The farmer is not expected to take an interest in the welfare of fishermen in general, nor the fisherman an interest in the welfare of all farmers.

Dyadic cooperation, being confined to the particular, and bringing logether people who differ from one another rather than those who 


\section{THE PHILIPPINES}

are alike does little to inhibit competition between the latter: fishermen compete with one another in the catching and sale of fish. Farmers compete with one another for access to arable land, and people of all social strata compete with others of their own strata for a share in the wide variety of services, franchises, and opportunities for employment dispensed by the government to those with the best political connections.

The disposition to provide for one's needs particularistically through exchange relationships of the dyadic type, a pattern of interaction which ties together individuals who differ from one another while making competitors of those who are alike, helps to explain why political parties, in the Philippines are structured to a high degree by the networks of personal relationships rather than by categorical bonds. It also helps to explain why both major parties are able to bring into their fold people of all social classes, occupations and regions. And this in turn, explains why it is possible for both parties to be identical in their social composition and in their policies.

The lure of power and dependency. The difference between two persons who cooperate-dyadically may lie in their occupations, as in the case of the farmer and the fisherman. But it may also lie in their unequal socio-economic status. This brings us to a second feature of Filipino behavior: The exceptionally strong disposition to seek or to accept one of two alternative roles - that of the powerwielding patron and that of the dependent client. There are several explanations for the strength of these dispositions among Filipinos. One explanation, economic in nature, lies in the marked inequality in the distribution of land which has characterized the Philippines in recent centuries. Many families own substantial tracts of agricultural land. A great many others own no land at all. The census of 1960 revealed that, roughly, forty per cent of the farm population of the Philippines lived on farms under full tenancy, and an additional fifteen per cent lived on farms which were partly under the tiller's ownership. Many of these full or partial tenants depend upon members of the landed gentry not only for access to arable land, but also for a variety of other things essential to their survival, among the most important of which are loans or gifts of grain or money at times of distress, free medical and other professional services, and the patron's intercession to help protect them against the rigorous enforcement of the law. Such benefits, going beyond the terms of the tenancy contract, are regarded as favors which must be repaid. Because of the tenant's poverty, repayment usually takes the non-material form of service. One type of service is the recipient's loyal support of any project of the patron which requires the participation of "little people". At election time, it is expected 


\section{THE PHILIPPINES}

that repayment will be made by voting and campaigning for the benefactor, should he choose to run for public office, or for whatever candidates he designates. Thus little people often find themselves in the position of dependents and followers, while "big people" often have leadership thrust upon them.

The disposition to accept the alternative roles of power-wielding leadership and of dependent followership also appears to be encouraged by certain patterns of child-rearing characteristic of the Philippines. Habits of dependency are fostered by a high degree of parental protectiveness and a relatively slight emphasis upon the early achievement of independence. At the same time, authoritarian parents and older siblings provide models of power-wielding patronship which children may hope to emulate later in life.

These patterns of power-wielding and dependency, so characteristic of Philippine society, also help to explain why relationships of leadership and followership, cutting across the lines of social class, are so important a part of the structure of Philippine political parties, and thus why the parties are identical.

Parochialism. The third phenomenon which helps to account for these and certain other characteristics of the party system is political parochialism, i.e. the tendency of rural Filipinos to choose their political alignments mainly on the basis of essentially local considerations. There appear to be several reasons for this high degree of parochialism in politics: First, dyadic cooperation, upon which Filipinos place such heavy reliance, requires that there be mutual trust between dyadic partners. This requirement is best met under conditions of geographic contiguity. Similarly, interpersonal rivalry, the obverse of dyadic cooperation, is most intense and persistent when the antagonists are in close proximity and insults can be tossed back and forth directly or through allies or neutrals known to both sides. As one's strongest allies and bitterest enemies are near at hand, elections for local offices in the Philippines are "hotter" than those for national offices.

Quite aside from the fact that they take greater interest in the outcome of local elections than of national ones-probably a common phenomenon in predominantly peasant societies - Filipinos find it both possible and necessary to choose their political alignments largely on the basis of the personal alliances and rivalries which exist within their towns and provinces. They find this to be possible because the presence of prosperous gentry families in almost every town provides the peasantry with natural leaders near at hand who, because of their wealth and accessibility, have more to offer them than can the national leaders of the two political parties. These gentry families in turn, because they command substantial 


\section{THE PHILIPPINES}

personal followings and because their independent wealth gives them some degree of immunity against governmental pressure, can choose their political alignments largely on the basis of the relationships which interest them the most - their blood and marital ties, their friendships, and their personal enmities.

Filipinos find it not merely possible but necessary to choose their political alignments largely on the basis of local considerations because the omnipresence of favoritism in the distribution of goods and services by the government, and the far from reliable or imper. sonal enforcement of the law - both of which, in practice, are under the control of municipal officials - means that the ordinary citizen's welfare and, not rarely, his physical security depend upon his ability to maintain good personal relationships with these local officials or with other local leader sufficiently powerful and near at the hand to protect him against their wrath. Under these circumstances, unflinching loyalty to a national leader or party not supported by the citizen's local patron is a luxury he can ill afford.

\section{POLITICAL ORGANIZATION}

It was stated that Philippine political structure consists in large part of networks of personal relationships, many of which cut across the categorical socio-economic boundaries that in most other democracies distinguish the bulk of the members of one party from the bulk of the members on another. A closer examination of this structure may be useful.

Briefly, four types of units participate in the struggle for political offices in the Philippines: individual politicians with their personal followings, factions composed of groups of leaders each with his own following, the political machines of "kingpins", and political parties. While these units overlap, they are structurally distinct and distinctive, and must be considered separately.

Personal followings. The strong disposition of Filipinos to create relationships of leadership and followership has been noted. Leaders and followers may be thought of as being the electrons and protons of Philippine politics. The atoms into which they arrange themselves are the personal followings of individual politicians. These consists in each case of a single leader, together with the various individuals who have chosen to follow him. Though at first sight such followings may appear to be discrete groups which pursue collective goals, closer examination shows their structure and function to be essentially dyadic. Each follower is bound to the common leader by a personal bond of loyalty, and repays the leader for particular rewards received or expected by helping him attain his 
own goal - the capture of a political office or some other position of power. There is little sense of solidarity among the followers beyond their common desire to see their leader installed in office. Often, instead, there is a lively rivalry between followers for the favor of their leader. The leader, in turn, finds his most obvious rivals to be other leaders, men of status equal to his own, with whom he competes for the allegiance of would-be followers.

Typically, the aims and loci of a simple personal following are narrowly local in nature. The leader's aim is to win and enjoy some local office. Geographically his range of influence and interest is narrow. While his constituency may be quite large, his strongest allies and followers, as well as his bitterest enemies, as has been suggested, are to be found among his neighbors and townmates. What occurs outside his community is of far less interest to him, or to his followers, than what takes place in his own town. If the leader is a party man - which he need not be - he is conscious of the existence of his party-mates in other parts of the country. But his sense of solidarity with them is weak, as is his antipathy towards their enemies.

Personal followings of this sort are the smallest multi-member units of Philippine politics. Next to simple dyads of leadership and followership, they are also the most stable units for they have the strongest most enduring hold upon the loyalty of ordinary voters. Out of them several types of larger political units - what might be called the molecules of Philippine politics - are constructed.

A personal following has a single leader. In small constituency - a village or a small town - a single leader may have a following among the voters sufficiently large to win elections. In larger constituencies, this is less likely to be the case. When loyalty is not institutional, ideological or charismatic, but personal and based upon the dyadic expectation of a quid pro quo - as generally is the case in Philippine politics - the span of control of any one leader has fairly narrow limits. As the number of his followers grows, his ability to maintain close ties with each of them decreases. Beyond a certain point the recruitment of new followers ceases to be profitable: Attempts to add more followers result in defections. If greater numbers of followers are to be brought together, as they must be, if elections in large constituencies are to be won, the personal followings of various leaders must somehow be combined. Two types of combinations of followings are common in the Philippines. One type is best termed a "faction" - the other is the multitiered political machine of a "kingpin".

Factions. Factions, - "groups" or "bandos" as they are often called, are found in constituencies where there are so many leaders 


\section{THE PHILIPPINES}

of personal followings that no single leader commands more than a fraction of the votes. In such constituencies several leaders, united by ties of kinship or affinity or by their common hostility to other leaders, may rally together to support one of their number at a particular election. When a number of leaders cooperate in this fashion for a number of elections in succession, and when they have a name for their group, one may speak of the presence of a faction. The leaders who head such a faction usually, also are members of the same party, though they need not be, for occasionally factional combinations cut across party lines. Certainly they need not in clude within their circle all of a party's local leaders. The most clear evidence of the existence factionalism in a town is to be found in the presence of three or four strong candidates at every local election, which usually means that several competing factions within the same party have supported rival candidates for the same office. But even when there are but two factions in a town, this must not be confused with simple bipartisanship. In pre-war days, and especially in the nineteen - thirties, when the members of one party ruled the roots in many provinces, lively contests between rival local factions of the same party were the norm in many towns. Since the achievement of Independence, which saw the emergence of a highly competitive two party system in most provinces and towns, rival local factions usually have been alligned with opposing national parties. Their factional cohesiveness, which distinguishes such local groups from mere local chapters of national parties, can be inferred from the not infrequent occurrence of party-switching by entire factions. Thus, should a group of local leaders affiliated with one party become dissatisfied with their treatment at the hands of that party's provincial or national leaders, they may change their party allegiance as a group, whereupon the opposing faction can be expected to switch parties also, but in the opposite direction. The distinguishing characteristic of a local faction in the Philippines, then, is that it consists of a number of leaders of more or less equal status held together not by their common membership in the same nation-wide political party but by personal ties existing between them. Such factions remain alliances, they rarely become unions. For the followers which each leader brings with him into the faction remain his personal clients. They do not become members of the faction as such. When they vote for a member of the faction other than their own leader, they do so at their leader's behest. If he chooses to reclaim his independence or to shift from one party or faction to another, his followers can be expected to go with him. In short, factions like the separate personal followings of which they are composed, are not discrete groups but are essentially dyadic in structure. 


\section{THE PHILIPPINES}

Factions then, are alliances among leaders of roughly equal prominence in the same constituency, bound together by horizontal ties of alliance between them. Their purpose is to minimize competition among what otherwise would be natural competitors so that they may hold office by turns.

Kingpins. The political machines of kingpins, found in some but by no means in all provinces, are combinations of a different type. They may be described as tiered pyramids of personal followings ruled by a great leader, the "kingpin", whose followers in turn command followers of their own. The kingpin, typically, exercises province wide leadership. Each of his sub-leaders commands influence in his respective town. Their sub-leaders, in turn have influence in their respective villages. Thus the machines of kingpins are combinations among persons of diverse stature, each seeking influence in a different constituency, bound together by a series of vertical ties having their apex in a provincial leader. They bind together non-competitors in order that each may compete more effectively against his own rivals.

Parties. Another type of political unit is the constituency organization of a nation-wide political party. Both major parties have such organizations in all provinces and in almost every town. In contrast to personal followings, factions and the political machines of kingpins, constituency party organizations are discrete, formally organized groups. At least in theory if not always in practice, they operate under clear cut sets of rules concerning membership and decision - making. Most - though not all - local political leaders belong to one or the other of the major parties. A candidate for a local office has a far better chance of winning if he is a member of a major party than if he is not. His chances are best if he is proclaimed his party's "official candidate." In such a case he will be permitted to designate election inspectors who represent his party at each polling place on election day - a source both of patronage and of protection against fraud at the polls. But one need not be an official party candidate, or even a member of a major party to win. It is a common practice of unsuccessful aspirants for official party candidacy to stay in the race and run for office as "Independent Nacionalistas" or "Independent Liberals." It is not unusual for such "rebel candidates" to be elected. Candidates without party affiliation win office far more rarely. Thus party membership is decidedly advantageous for political leaders, and most politicians are party members. But membership does not imply a high degree of party discipline or even of party loyalty. A local leader affiliated with a political party may support his party's official candidate and urge his followers to do the same. Or he may not. The political party is but one of the units which seek the loyalty of 


\section{THE PHILIPPINES}

politically active Filipinos, and it may not be the most successful one.

The interrelationship of political structures: Leaders of personal followings, factions, kingpins, and party organizations are found at all levels of political activity from the village upwards. But the strength of the hold of these diverse structures upon the loyalty of political activists varies from one level to another. The limited evidence presently available suggests that party labels are most important in contests for national offices and least important in village and town politics, where ties of kinship, friendship and patronship-clientship largely determine the voters' choice of candidates. Factions appear to be most prevalent in municipal and provincial politics. Kingpins usually are men who exercise province-wide leadership.

The relative importance of the types of structures described here also varies from province to province, and over time. Purely factional politics was most widespread during the pre-war period and now is most common in the more isolated, predominantly rural provinces. Voting along party lines has been most strongly in evidence since Independence in general, and in the more largely urban provinces near Manila in particular.

Still, partisanship has far from supplanted loyalty to other structures. These structures persist and may conflict with each other. Personal followings factions and the organizations of kingpins, especially, may interfere with the effective functioning of the party system. These structures, narrowly local in extent and interest, and held together not by the common categorical identification of their members but by networks of personal ties and shared enmities, are better suited for the satisfaction of the concrete, short-run wants of their individual members than for the championship of policies. None is well suited to serve as the instrument of disciplined, nationwide parties of the modern type. Yet these structures have such a strong hold upon the allegiance of politicians and rank-and-file political activists that they often succeed in usurping the functions of the formally-organized local chapters of the political parties.

Thus official party candidates for local offices often are chosen not by the local party conventions for which the rules of both parties provide, but by a few powerful provincial party leaders. The interests of these leaders may differ substantially from those of the mass of party members in a locality, or of the party as a nation-wide organization. Acting in their party's name, but in their personal interest or the interest of their faction, they may commit their party to the support of local candidates who have no understanding of the programs devised by the party's national leadership, little loyalty 
to these national leaders, and little interest in the long-term welfare of the party as an institution. Indeed, such leaders may prefer to allow their party to lose a local election rather than see a mayorship fall into the hands of a rival leader within their party. They may "junk", their party's candidates for national offices in order to create alliances of convenience with the leaders of the opposing party. And they can be expected to withold support from party policies which jeapordize their efforts to create localized personal followings drawn from all social strata.

It may be useful, at this point, to summarize some principles which have emerged in the course of the foregoing survey of the structure of Philippine politics. First, many Filipinos join political parties and act within these parties, not as lone individuals but as members of pre-existing structures to the special needs of which the parties must accomodate themselves. Second, these pre-existing structures may straddle the line which separates one party from another, or the line which separates those who are loyal party men from those who are not. Some members of a following, a faction or a kingpin's machine may feel strongly committed to the support of the leader's party. Others may regard themselves as weakly committed, uncommitted, or may have ties with the opposing party. Thus the "boundaries" of parties are unclear. Third, the links which unite those who work together in politics, whether as members of individual followings, factions, the machines of kingpins, or parties, are in large part "vertical" dyadic links of leadership and followership which cut across the boundaries of social class. They bind poor voters to petty leaders of somewhat higher socio-economic status while tying these in turn to leaders of substantial wealth and social standing. They bind local candidates to candidates for higher offices in relationships of mutual aid. They attach local followings and factions to nation-wide political parties. Fourth, these links unite individuals of all occupations, economic interests, and religious or secular persuasions. Fifth, they unite individuals - or pit them against one another - on the basis of purely geographic considerations. Thus, in national elections for the Presidency or the Senate these links may lead voters of diverse factions and parties to support the same regional favourite son, while in local contests there may be irreconcileable rivalries between neighboring villages. Such geographical loyalties and antipathies impede the growth of disciplined, policy-oriented parties.

Viewing the Philippine political party system as a whole one finds in each province two pyramids of political organization, having their roots in the villages and their apexes in the provincial capital. The pyramids are composed, at each level, of identical parts. The parts often are pre-fabricated, being composed of individuals whose 


\section{THE PHILIPPINES}

mutual ties antedate their party identification. The parts are interchangeable and, not rarely, are interchanged with the corresponding units of the opposite political party. Because they are composed of such identical and interchangeable parts, the two parties themselves must be identical as well. Each, if it is to maintain its competitive position vis a vis the other, must govern in such a way as to satisfy to some degree members of all social classes. Neither, if it is to maintain its competitive position in every province, can afford to neglect the interest of any region by giving too much attention to the needs of any other region. Each must attend to the needs of industry and commerce in the cities and towns and to the needs of the great majority of agriculturists who live in the country's villages. And each must cater to the special demands not only of the Catholic majority but also of the Moslems who predominate in several southern provinces and of the Iglesia ni Cristo, a small but tightly-knit and politically aggressive sect which holds the balance of power between the parties in many constituencies.

But how is it possible for both major parties to maintain a sub. stantial following among all classes, all interests and in all regions of the country $-\mathrm{a}$ feat unattained by political parties in most other democracies? Both parties do so by means of the same strategy. On the one hand, they avoid clear and categorical commitments on controversial and potentially socially divisive questions of general policy. On the other hand, they cultivate some, among the most assertive and politically influential individuals of every social stratum, interest group and region through favored treatment in the distribution of a wide variety of rewards. This is made possible by the absence of strict and impartial law-enforcement, a deficiency characteristic of government in a society which attaches a high value to favoritism and little value to general rules. Thus, party leaders and their supporters of all classes and occupations can expect to receive special rewards appropriate to their social station, while villages, towns, and whole provinces which side with the winning party can expect to be favored in the allocation of public workes funds and a variety of services. By concentrating upon the particularistic distribution of rewards to their friends among all sectors of society while eschewing clear commitments on controversial issues of general policy, both parties can avoid the appearance of favoring any sector of society at the expense of another.

\section{POLITICAL RECRUITMENT AND POLITICAL PARTIES}

Recruitment into politics and into the ranks of the political parties is unrestricted. The write-in system of voting employed in the Philippines assures that anyone desiring to run for public office 


\section{THE PHILIPPINES}

who fulfills certain simple requirements may be a candidate on election day. Party membership is not regarded as a prerequisite. Almost any Filipino of the upper or middle classes who has an urge to be a politician, money to spend on a campaign, and who believes that he can persuade others to vote for him, regards himself - and is generally assumed to be-qualified to run for public office. Neither apprenticeship as a worker in a political party nor special knowledge of public affairs is thought to be necessary. At each election, countless members of the rural gentry and the middle class throw their hats into the political ring with but the dimmest knowledge and the vaguest convictions concerning affairs of government and with scant experience in politics. Their reasons, usually, are purely private ones - to demonstrate, by their ability to attract votes, that they are "big men" in their communities and to enjoy the psychological and material rewards of office. A major stimulous to candidacy is the belief that one has a potential following. This especially has encouraged candidacies from certain occupations. During the early decades of the century, landowners who controlled the votes of the tenants predominated. Recent years have witnessed the entry into politics of many professional men: lawyers, doctors, and dentists with large numbers of clients who are arrears in their payment of fees, who owe them "debts of gratitude" and thus can be counted upon to work for them; middle and higher level bureaucrats who, though stationed in Manila, have done favors for many town and province mates; and more recently, the owners of industrial establishments with many employees.

For those who run for office, party membership offers a decided advantage, of course. But membership is acquired easily. In practice, entry into the ranks of either party is open to all. In the absence of regularly-enforced formal procedures of affiliation, a would-be candidate may call himself a member of whatever party he wishes, a choice he may not make until shortly before election day. The party will not protest, for it cannot risk driving him and his followers into the arms of the opposing party by disowning him. When several party men aspire to office, as when a strong newcomer wishes to run despite the presence of a veteran party candidate, the party's national leaders may declare a "free zone".

While a party's leaders rarely object if a candidate, not chosen by themselves, runs under its label, they do little to help such candidates. Even an official party candidate can expect little or no financial help from his party, for as has been noted, the financing of each candidate's campaign is assumed to be his own responsibility as it is assumed that the fruits of victory will be enjoyed mainly by himself. But if he is elected, even a "rebel candidate" who has run against his party's official candidate is entitled to assume a position 
of leadership in his party, displacing veteran party leaders who no longer hold public office. As has been noted in the case of two Presidents, even party switchers find no obstacle to the rapid assumption of high positions within their new party. Thus access to power, in both major parties is virtually unrestricted. It depends almost exclusively upon the would-be politician's ability to mobilize voters on his own accord.

\section{PARTIES AND PUBLIC POLICY}

What are the programs of the two parties? In a country where the leaders of each party are united by little more than their common desire to be elected, and where both groups of leaders to an equal degree seek the support of all sectors of society, there are no party programs, supported by a party's leadership as a whole, which are distinctive, coherent, and which represent genuine commitments to the electorate. There are only the personal programs of individual Presidents. Insofar as they are able to do so - and if they do not happen to be feuding with the President the leaders of his party in the Senate and the House of Representative will attempt to rally support for his principal measures among their party-mates in Congress. But as united party support for presidential measures is never certain, and usually must be paid for by the distribution of favors to recalcitrant senators and congressmen, most presidents find it necessary to rely heavily upon the votes of friendly members of the opposing party.

Presidential programs differ from each other to some degree. Each new President, before he assumes office, or sometimes after that event, formulates a program for his administration which may be somewhat different from that of his predecessor. He devises this program in accordance with his personal convictions, and the advice of his principal lieutenants in the Executive branch and in Congress, usually staying within the fairly narrow limits set by the expectations of various organized and unorganized interests which no President can ignore. His ability to enact his program is limited not only by his uncertain control over his party - mates in Congress but also by the occasional indiscipline of the members of his Cabinet and their subordinates, as well as by a lack of public interest in and support for presidential programs as such. Typically, the election of a new President is folloyed by lively and protracted journalistic speculation concerning the names of possible cabinet appointees and by an almost total lack of interest in, or discussion of, the Presidentelect's legislative program.

The cyclical alternation between Presidents belonging to one party and those belonging to the other produces no cyclical 


\section{THE PHILIPPINES}

alternation of policy, however. Instead, changes of policy are secular, reflecting a gradual change in the balance of power among the country's main interests, the emergence of new needs that must be met, and broad if gradual changes in the mood of public opinion. Thus in the field of foreign policy, as the popular spirit of nationalism has grown stronger in recent years, each succeeding President has been more ready to assert this nation's independence of the United States in matter of foreign policy and more willing to defend the interest of the nation's growing industrial entrepreneurial community against foreign competition. Slight deviations from this and other secular trends are to be explained by the difference between the personal views of individual Presidents, rather than by their party affiliation.

While observers from other countries, accustomed to expect a spirited doctrinal debate between two clearly distinctive parties, may regret the absence of the seasonal alternation of policies found in their own countries as parties replace each other in control of the government, the secular character of policy change characteristic of the Philippines offers certain decided advantages. It means that in a country where political passions are easily inflamed, the biennial electoral contest between parties is not amplified by ideological or class conflict. It also means that in a highly individualistic society, where each new office holder wants to start afresh with new programs, abandoning those of his predecessors simply because they are not his own, a higher degree of continuity of administration is maintained than might otherwise be the case.

A system of identical multi-class parties is a rare phenomenon. Some students of Philippine politics, aware that differences between parties are the norm in most modern democracies, predict that the Philippine party system will transform itself in the not too distant future into one marked by a rivalry between a liberal or radical party representing the lower class and a conservative party drawing its strength from the middle and upper classes. While this may happen eventually, the writer finds no evidence to justify the prediction that it will occur in the near future. It seem unlikely that the existing parties will soon adopt sharply contrasting positions identifying them with one class or the other. Such a change would necessitate an abandonment of their vertical dyadic structure, a type of structure which so far has enabled them to win large nationwide majorities and to return their leaders to office time and again.

\section{UNITY AND DIVISION IN THE BODY POLITIC}

Still the ability of the major parties to continue to satisfy a broad spectrum of interests as they have done in the past would be much 


\section{THE PHILIPPINES}

reduced were there to appear irreconcilable divisions within Philippine society as a whole. What kinds of divisions are likely to develop? The Philippines has been spared certain types of conflict which plague a number of other Asian countries. Regional rivalry is not a serious problem. Spanish colonialism, through the Hispanization of the upper class and the conversion to Catholicism of the mass of common people, produced a highly homogenous Christian population which dominates all but a few provinces of the archipelago. A uniform system of public and private education employing English as the language of instruction during and since the American period, as well as six decades of popular participation in national politics has resulted in a uniformity of party alignment throughout the nation which exceeds that to be found in most democracies and which becomes more uniform with each election. Communalism is not a serious problem. Non-Catholics make up a small minority, whose treatment at the hands of the Catholic majority has been relatively benign. Protestants and Moslems have been elected to high positions by popular majorities composed largely of Catholic voters. While some Moslem leaders in the South complain that their provinces have suffered neglect at the hands of the central government, this is a complaint common to all thinly populated frontier provinces. Moslems as a religious community have not been subject to persecution. Inevitably, there are disputes over property between long - settled Moslems and Christian immigrant in the South. And there is some fear among responsible leaders in Manila that Indonesian irredentism, if its appeal should take a religious form, might have some attraction to Moslem Filipinos. But so far there have been no attempts to create a Moslem party. In the Moslem provinces as elsewhere, rival leaders compete against each other under the banners of the two nationwide parties. Pagan minorities, many of whom are engaged in swidden agriculture, doubtless suffer neglect if for no other reason than their inaccessibility and lack of education. But in a country that shares no mountain frontier with a hostile neighbor, these pagan minorities lack the strategic importance of the hill peoples of mainland Southeast Asia. The Chinese population, predominantly urban and commercial, while economically powerful is becoming less so as Filipino entrepreneurs, assisted by their government, carve out for themselves a larger place in the commercial and industrial sectors of the economy. As few Chinese enjoy Philippine citizenship because of the high cost of naturalization, their capacity for political action, whether offensive or defensive is slight. There are conflicts of interest, of course, between the city and the countryside. The last decade has witnessed a running battle between the representatives of the producers of agricultural commodities, especially sugar, who wish to preserve their favored position behind the American 


\section{THE PHILIPPINES}

tariff wall, and the new leaders of Philippine industry who seek protection against American and other foreign products. The clash is softened somewhat by the fact that many of the most progressive leaders of agriculture have begun to shift their investments to industry. Over the passing years the voice of agriculture has been more muted as the voice of industry has grown louder. But neither agriculture or industry as a whole has formed a special attachment to either party. In the sugar provinces, Nacionalista planters run for office against Liberal planters, and neither party is consistently stronger than the other in industrial Manila. The great majority of Congressmen who come from rural districts are able to satisfy their rural constituents by providing them with nationally financed public works projects and services while using their influence in Congress and in the executive departments to further the interests of their financial backers in Manila. In short, there is no sign at present that the parties will be forced, in the near future, to align themselves with opposing sectors of the society.

There remains the question as to whether a new third party, radical in ideology and appealing mainly to the poor, could win sufficient strength to displace one of the existing major parties as the principal party of opposition. On the whole, the fate of third parties in the Philippines has not been a happy one. The bifactionalism which is the norm in most municipalities and provinces makes possible the mobilization of local organizational support for only two major parties. With a few striking exceptions - notably the Vice Presidential candidacy of Sergio Osmeña Jr. in 1961 - those who run for high national offices without major party support have done quite poorly at the polls. Parties of a clearly radical nature it is true have on several past occasions won a substantial share of the congressional and gubernatorial votes in the half-dozen provinces of central Luzon. This region, where the incidence of agricultural tenancy far exceeds that of other regions of the country, has long been a center of agrarian unrest. But even here, radical parties have been short - lived. Their decline, only partly to be explained by governmental measures of suppression, has generally been followed by the electorate's return to the support of the two major parties. The fact that such radical movements have little prospect of spreading to other regions, and thus have no real chance of winning control of the national government, serves to discourage political leaders who might otherwise cast their lot with such parties. The voters' preference for candidates who have money to spend and who are likely to win office quickly further serves to discourage radical candidates genuinely representative of the poor. 


\section{THE PHILIPPINES}

If the Left is to grow in strength and influence, such growth probably will take place within the folds of both of the two major parties through middle and upper-class candidates who, while leaning more to the left than most of their colleagues, win election in the traditional manner by attending to the needs of all strata in their constituencies through the particularistic distribution of the usual rewards. In short, it seems likely that for some time to come, the two existing major parties will adjust to any change in the balance of power in Philippine society by adopting the same new policies and modifying the same old ones, in order to continue to play the roles of "aggregators" of all interests, while retaining their positions near the dead center of the political storm.

All copyrights in this article are exclusively reserved by the author. 